\title{
Concentration of mycotoxins and chemical composition of corn silage: A farm survey using infrared thermography
}

\author{
P. Schmidt, ${ }^{* 1}$ C. O. Novinski, ${ }^{*}$ D. Junges, $†$ R. Almeida, ${ }^{*}$ and C. M. de Souza* \\ *Departamento de Zootecnia, Universidade Federal do Paraná, Curitiba, PR, Brazil \\ †Escola Superior de Agricultura "Luiz de Queiroz," Universidade de São Paulo, Piracicaba, SP, Brazil
}

\begin{abstract}
This work evaluated the chemical composition and mycotoxin incidence in corn silage from 5 Brazilian dairy-producing regions: Castro, in central-eastern Paraná State $(\mathrm{n}=32)$; Toledo, in southwestern Paraná $(\mathrm{n}=20)$; southeastern Goiás $(\mathrm{n}=14)$; southern Minas Gerais $(\mathrm{n}=23)$; and western Santa Catarina $(\mathrm{n}=20)$. On each dairy farm, an infrared thermography camera was used to identify 3 sampling sites that exhibited the highest temperature, a moderate temperature, and the lowest temperature on the silo face, and 1 sample was collected from each site. The chemical composition and concentrations of mycotoxins were evaluated, including the levels of aflatoxins $\mathrm{B}_{1}, \mathrm{~B}_{2}, \mathrm{G}_{1}$, and $\mathrm{G}_{2}$; zearalenone; ochratoxin $\mathrm{A}$; deoxynivalenol; and fumonisins $\mathrm{B}_{1}$ and $\mathrm{B}_{2}$. The corn silage showed a highly variable chemical composition, containing, on average, $7.1 \pm 1.1 \%$, $52.5 \pm 5.4 \%$, and $65.2 \pm 3.6 \%$ crude protein, neutral detergent fiber, and total digestible nutrients, respectively. Mycotoxins were found in more than $91 \%$ of the samples, with zearalenone being the most prevalent (72.8\%). All samples from the Castro region contained zearalenone at a high average concentration (334 \pm 374 $\mu \mathrm{g} / \mathrm{kg}$ ), even in well-preserved silage. The incidence of aflatoxin $\mathrm{B}_{1}$ was low $(0.92 \%)$. Silage temperature and the presence of mycotoxins were not correlated; similarly, differences were not observed in the concentration or incidence of mycotoxins across silage locations with different temperatures. Infrared thermography is an accurate tool for identifying heat sites, but temperature cannot be used to predict the chemical composition or the incidence of mycotoxins that have been analyzed, within the silage. The pre-harvest phase of the ensiling process is most likely the main source of mycotoxins in silage.
\end{abstract}

Key words: aflatoxin, dairy cow, epidemiology, maize, zearalenone

Received July 15, 2014.

Accepted May 12, 2015.

${ }^{1}$ Corresponding author: patricks@ufpr.br

\section{INTRODUCTION}

Silage quality and concentration of mycotoxins can vary broadly and such variation can be due to many factors, including forage composition, losses during anaerobic storage, and aerobic deterioration after the silo is opened. The aerobic phase can alter the chemical composition and affect the safety of the silage. Under these conditions, yeast can oxidize lactic acid and increase silage $\mathrm{pH}$, which then facilitates the growth of other microorganisms (McDonald et al., 1991). The elevated $\mathrm{pH}(>6.0)$ caused by the growth of spoilagecausing yeasts results in the active growth of toxigenic fungi during the feed-out phase, particularly in poorly managed silage (González-Pereyra et al., 2008).

Mycotoxins are secondary metabolites of certain fungal genera and cause several undesirable effects in humans and animals. Silage can be an important mycotoxin source, and little is known about the potential synergistic or antagonistic effects of mycotoxins that result in chronic health problems (Driehuis et al., 2008a). Mycotoxins can be derived from the field or introduced during ensilage; contamination during ensilage is directly related to air infiltration during storage and after the silo is opened, occurring mainly in high-porosity silos or in silos with a low rate of silage removal (González-Pereyra et al., 2008).

Brazilian dairy farmers frequently associate reproductive or metabolic disorders with the intake of fungispoiled silages. However, these feeds are not analyzed to determine the presence of mycotoxins because of high analytical costs and the lack of reference values for forages. Few data are available on the incidence of mycotoxin under controlled field conditions. Driehuis et al. (2008b) performed a survey in which 20 mycotoxins in corn $(\mathrm{n}=140)$, grass $(\mathrm{n}=120)$, and wheat $(\mathrm{n}=$ 30) silage samples were evaluated in the Netherlands. The incidence of Fusarium-related mycotoxins, such as deoxynivalenol (DON) and zearalenone (ZEA), was high in whole-crop corn silage (72 and $49 \%$, respectively), and these mycotoxins co-occurred in $46 \%$ of the samples. Other toxins, such as fumonisins, aflatoxins, $\mathrm{T} 2$-toxin, and roquefortine $\mathrm{C}$, were found at low inci- 
dences (below 2\%) or were not detected. In Argentina, González-Pereyra et al. (2008) analyzed 60 corn silage samples from different sections of 2 silos. All samples contained fungal colonies, with ZEA, DON, and fumonisin being the primary toxins. These toxins co-occurred in $83.5 \%$ of the samples. The authors also analyzed the concentration of aflatoxin $\mathrm{B}_{1}\left(\mathbf{A F B}_{1}\right)$, which was found in all samples from the visible moldy upper section of the silos, but only in 6 samples from the middle section, at low concentration $(<10 \mu \mathrm{g} / \mathrm{kg})$.

Silage may contain a complex mixture of mycotoxins that originate from preharvest contamination, mainly with Fusarium spp., and postharvest contamination with toxins produced by fungal species such as Aspergillus and Penicillium (Cheli et al., 2013). The feed-out phase is a critical time during which mold and mycotoxin contamination of silage can occur. During this phase, differences in microaerophilic conditions, humidity, $\mathrm{pH}$, and farm management practices produce differences in the silo environment. Thus, reports on mycotoxin occurrence and distribution in the literature are inconsistent.

The growth of spoilage microorganisms in silages produces heat, which is a typical indicator of aerobic degradation (Kung et al., 2000). However, the relationships among silo face temperature, silage quality, and concentration of mycotoxins remain poorly understood. Borreani and Tabacco (2010) evaluated the temperature at 11 locations on 54 silos and correlated the temperature with chemical composition and microbial count. Samples from peripheral areas showed greater temperatures, $\mathrm{pH}$ values, and yeast counts than samples from the central area. Those authors concluded that temperature is linked to microbial activity and can be an important indicator of the early stages of aerobic degradation. However, the concentration of mycotoxins was not assessed in that study.

Infrared thermography (IRT) is a useful tool for detecting variations in temperature over large areas, such as the working face of silos. However, our previous trials (unpublished data) have shown that IRT measurements are strongly influenced by the external environment and that the relevance of the values must be considered with caution.

In this study, a survey on whole-crop corn silage obtained from 109 dairy farms in 5 regions in Brazil was performed using IRT to discern 3 sites (the highesttemperature site, a moderate-temperature site, and the lowest-temperature site) of the silo face for sampling. The chemical composition and concentrations of mycotoxins in these 327 samples are presented. Correlations of these data with IRT, internal (100-mm depth) silage temperature, and ambient temperature were assessed.

\section{MATERIALS AND METHODS}

\section{Sample Collection and Temperature Measurements}

In total, 109 farms were visited between May and September 2010 by researchers from the Centro de Pesquisas em Forragicultura (CPFOR), Curitiba, Brazil. The farms were located in 5 dairy-producing regions: Castro, in central-eastern Paraná State $(\mathbf{C A}, \mathrm{n}=32)$; Toledo, in southwestern Paraná (TL, $\mathrm{n}=20)$; southeastern Goiás (GO, n = 14); southern Minas Gerais (MG, n = 23); and western Santa Catarina (SC, n = 20). These 5 counties are located in the south (CA, TL, and $\mathrm{SC}$ ), southeast (MG), and midwest (GO) regions of Brazil. All livestock were fed whole-crop corn silage that was ensiled in 2010. The farm size and technology varied according to the regional conditions; dairies ranged from 15 to 3,000 lactating cows. In each region, farms were selected from a list provided by the local cooperative of milk producers, which included ranked data on average daily milk production and herd size. Farms were classified into 3 groups according to these variables. To be representative of the region, 7 to $10 \%$ of the farms from the list were selected, including farms from the 3 groups. The staff of the cooperative contacted the farmers to schedule the visits.

At each farm, the ambient temperature (AT) in the shade was measured approximately $3 \mathrm{~m}$ in front of the silo face using a digital thermometer. An additional survey of 32 questions was administered at each farm. This survey included details on corn production, the ensiling process, and the management of feed-out.

Using an infrared thermography camera (Fluke Ti25; Fluke Corp., Lynnwood, WA), the working face of the silo was scanned to identify 3 different sites on the silo face: $\mathbf{H}=$ the highest temperature; $\mathbf{M}=$ moderate temperature; and $\mathbf{L}=$ the lowest temperature. These sites were automatically identified by the camera. Loose silage or visibly rotten sites were not considered when determining these sites. At each site, the external temperature (ET; superficial), as measured by IRT, and the internal temperature (IT), which was measured with a probe at a length of $100 \mathrm{~mm}$, were taken using an infrared thermometer coupled with a probe (Fluke 66; Fluke Corp.).

At each site, after the temperatures were measured, samples $(1,100 \mathrm{~g})$ were collected from the surface layer (maximum depth $=150 \mathrm{~mm}$ ) and immediately vacuum sealed (Orved \& Brock EcoVacuum, Musile di Piave, Italy) at the farm. The samples were kept in a styrofoam box at room temperature. The maximum duration between sample collection and processing was $3 \mathrm{~d}$ $(2.3 \pm 0.5)$. 


\section{Sample Processing and Analysis}

All 327 samples were processed similarly. A wet sample $(25 \mathrm{~g})$ was collected to evaluate the silage $\mathrm{pH}$ in water (Kung et al., 1984). The remaining samples were dried in a forced-air oven at $60^{\circ} \mathrm{C}$ for $72 \mathrm{~h}$ to determine the DM content and the chemical or mycotoxin composition. Dry samples were ground in a Wiley mill (MA 680; Marconi Ltda., Piracicaba, SP, Brazil) to allow passage through a 1-mm screen. A 50-g subsample was obtained for chemical composition analysis. The analytical DM was determined through oven-drying at $105^{\circ} \mathrm{C}$ for $24 \mathrm{~h}$ (AOAC International, 1998). Ash was determined via combustion at $550^{\circ} \mathrm{C}$ for $6 \mathrm{~h}$. Total $\mathrm{N}$ was determined using the Dumas method (Wiles et al., 1998) with an N analyzer (Leco FP-528, St. Joseph, MI). The NDF content, which was determined using Q-amylase and sodium sulfite (Van Soest et al., 1991), and the ADF content (Goering and Van Soest, 1970) were adapted for the Ankom ${ }^{200}$ Fiber Analyzer (Ankom Technology, Fairport, NY) according to the Ankom Technology procedures. The ether extract content was determined using Ankom filter bag technology (AOCS, 2008). The TDN values were calculated using the equation described by Weiss et al. (1992) and NRC (2001), with values of 16 and $7 \%$ for nitrogen bound to NDF and ADF, respectively (Sniffen et al., 1992). A processing adjustment factor of 0.94 was applied in accordance with NRC (2001) procedures.

Another dry subsample (300 g) was sent to the Laboratory of Mycotoxicological Analysis (LAMIC) of the Federal University of Santa Maria (Santa Maria, RS, Brazil). The samples were prepared as described by Varga et al. (2012). After grinding and homogenization, $5.00 \pm 0.01 \mathrm{~g}$ of silage was subjected to a 2-step extraction procedure using acetonitrile, water, and a formic acid-based solvent. These steps were individually performed for each mycotoxin. Liquid chromatography/ mass spectrometry (LC-MS/MS) was used to identify aflatoxins $\left(\mathrm{B}_{1}, \mathrm{~B}_{2}, \mathrm{G}_{1}\right.$, and $\left.\mathrm{G}_{2}\right)$, ZEA, DON, ochratoxin $\mathrm{A}(\mathbf{O T A})$, and fumonisins $\mathrm{B}_{1}$ and $\mathrm{B}_{2}\left(\mathbf{F} \mathbf{B}_{1}\right.$ and $\left.\mathbf{F} \mathbf{B}_{2}\right)$ in a single run (AOAC International, 1998). The system consisted of an HPLC (Agilent 1100, Agilent Technologies, Santa Clara, CA) coupled to an API 5000 triple quadrupole mass spectrometer (Applied Biosystems, Framingham, MA). The quantification limits were as follows (in $\mu \mathrm{g} / \mathrm{kg}$ of $\mathrm{DM}$ ): aflatoxins $=1$; ZEA $=10$; $\mathrm{DON}=140 ; \mathrm{OTA}=2 ;$ and fumonisins $=50$.

Because reference values for the concentrations of mycotoxins in silage were unavailable, based on published data and international regulations (Helferich et al., 1986; Coppock et al., 1990; Ingalls, 1996; Richard et al., 1996; Wood and Trucksess, 1998; FDA, 2001; FAO, 2003), we proposed a maximum acceptable value
(MAV) for each mycotoxin in the corn silage by considering a standard high-producing cow that could consume $14 \mathrm{~kg}(\mathrm{DM})$ of corn silage per day. Other mycotoxin sources were not considered when establishing these values. The established MAV for corn silage were as follows (in $\mu \mathrm{g} / \mathrm{kg}$ of $\mathrm{DM}$ ): aflatoxin $\mathrm{B}_{1}=19$; ZEA $=285 ; \mathrm{DON}=930 ;$ OTA $=5 ;$ and fumonisin $\mathrm{B}_{1}+\mathrm{B}_{2}$ $=1,000$.

Because comparing different samples with different concentration of mycotoxins and incidences is extremely difficult, we proposed a ponderal mycotoxin index (PMI). The goal was to integrate the occurrence of mycotoxins and their respective concentrations into a unique index. This allowed us to compare corn silage samples with each other and to correlate a unique mycotoxin value to temperature or chemical composition variables. This index was calculated by considering the concentration of each mycotoxin in a sample, the MAV for each mycotoxin and its incidence as follows (DM basis):

$$
\begin{gathered}
\mathrm{PMI}=\left[\left(\mathrm{AFB}_{1} / 19\right)+(\mathrm{ZEA} / 285)+(\mathrm{OTA} / 5)\right. \\
\left.+(\mathrm{DON} / 930)+\left(\mathrm{FB}_{1}+\mathrm{B}_{2} / 1,000\right)\right] \times[1+(\mathrm{PN} / \mathrm{TN})]
\end{gathered}
$$

where $\mathrm{AFB}_{1}=$ aflatoxin $\mathrm{B}_{1}$ concentration $(\mu \mathrm{g} / \mathrm{kg})$; ZEA = zearalenone concentration $(\mu \mathrm{g} / \mathrm{kg}) ;$ OTA = ochratoxin A concentration $(\mu \mathrm{g} / \mathrm{kg})$; DON = deoxynivalenol concentration $(\mu \mathrm{g} / \mathrm{kg}) ; \mathrm{FB}_{1}+\mathrm{B}_{2}=$ fumonisin $\mathrm{B}_{1}+\mathrm{B}_{2}$ concentration $(\mu \mathrm{g} / \mathrm{kg}) ; \mathrm{PN}=$ number of mycotoxins producing a positive test result in this sample; and $\mathrm{TN}=$ total number of evaluated mycotoxins. The denominator values are the MAV established for each mycotoxin. The remaining aflatoxins $\left(\mathrm{B}_{2}, \mathrm{G}_{1}\right.$, and $\left.\mathrm{G}_{2}\right)$ were not considered in the PMI formula because they were not detected in any sample $(\mathrm{n}=327)$.

The adoption of a correction factor based on the number of mycotoxins found in each sample was justified due to the potentially detrimental interactive effect on the animals consuming the silage when more than one mycotoxin is found in feed (Driehuis et al., 2008a). However, the nature and magnitude of this effect remain unknown.

\section{Statistical Analysis}

The means and standard deviations of the chemical composition of the silage were calculated for each variable. The PMI, which is a single value for mycotoxins, was established to improve the normality of the data distribution and was used to estimate the Pearson linear correlation between PMI and temperature measurements or chemical composition of the silage. Analyses were performed using the CORR procedure of SAS 
Table 1. Descriptive statistics of the composition and temperature of corn silage in a farm survey $(\mathrm{n}=327)$

\begin{tabular}{|c|c|c|c|c|}
\hline Item & Mean & $\mathrm{SD}$ & Minimum & Maximum \\
\hline DM (\%) & 32.4 & 5.0 & 19.8 & 49.1 \\
\hline $\mathrm{CP}(\%$ of $\mathrm{DM})$ & 7.1 & 1.1 & 3.3 & 10.7 \\
\hline NDF ( $\%$ of DM) & 52.5 & 5.4 & 36.8 & 72.7 \\
\hline $\mathrm{ADF}(\%$ of $\mathrm{DM})$ & 26.3 & 4.1 & 16.1 & 41.8 \\
\hline Ether extract (\% of DM) & 2.8 & 0.6 & 0.83 & 4.88 \\
\hline Lignin $(\%$ of $\mathrm{DM})$ & 4.0 & 1.3 & 0.86 & 9.36 \\
\hline TDN (\% of DM) & 65.2 & 3.6 & 50.2 & 74.1 \\
\hline Ash $(\%$ of $\mathrm{DM})$ & 3.3 & 1.0 & 1.1 & 10.9 \\
\hline $\mathrm{pH}$ & 3.78 & 0.18 & 3.34 & 4.54 \\
\hline $\mathrm{PMI}^{1}$ & 1.35 & 2.1 & 0.0 & 19.5 \\
\hline Internal temperature ${ }^{2}\left({ }^{\circ} \mathrm{C}\right)$ & 28.8 & 7.7 & 13.7 & 55.3 \\
\hline External temperature ${ }^{2}\left({ }^{\circ} \mathrm{C}\right)$ & 23.7 & 6.6 & 11.6 & 46.3 \\
\hline Ambient temperature $\left({ }^{\circ} \mathrm{C}\right)$ & 20.9 & 6.7 & 7.0 & 36.0 \\
\hline
\end{tabular}

${ }^{1} \mathrm{PMI}=$ ponderal mycotoxin index: $\mathrm{PMI}=\left[(\mathrm{AFB} 1 / 19)+(\mathrm{ZEA} / 285)+(\mathrm{OTA} / 5)+(\mathrm{DON} / 930)+\left(\mathrm{FB}_{1}+\right.\right.$ $\left.\left.\mathrm{B}_{2} / 1,000\right)\right] \times[1+(\mathrm{PN} / \mathrm{TN})]$, where $\mathrm{AFB}_{1}=$ aflatoxin $\mathrm{B}_{1}$ concentration $(\mu \mathrm{g} / \mathrm{kg}) ; \mathrm{ZEA}=$ zearalenone concentration $(\mu \mathrm{g} / \mathrm{kg})$; OTA = ochratoxin A concentration $(\mu \mathrm{g} / \mathrm{kg}) ; \mathrm{DON}=$ deoxynivalenol concentration $(\mu \mathrm{g} / \mathrm{kg})$; $\mathrm{FB} 1+\mathrm{B} 2=$ fumonisin $\mathrm{B}_{1}+\mathrm{B}_{2}$ concentration $(\mu \mathrm{g} / \mathrm{kg}) ; \mathrm{PN}=$ number of mycotoxins producing a positive test result in this sample; and $\mathrm{TN}=$ total number of evaluated mycotoxins.

${ }^{2}$ The internal temperature was measured using a probe, and the external temperature was measured using an infrared thermometer.

(version 9.3, SAS Institute Inc., Cary, NC) at a $95 \%$ confidence level.

For the mycotoxin analyses, the Shapiro-Wilk test was applied to evaluate the normality of the data. This test showed a left skew in the curve, which was caused by a high number of samples with undetectable values for each mycotoxin evaluated. Thus, the data were categorized as test-positive or test-negative, and an adjusted odds ratio was estimated for the incidence of each mycotoxin at each temperature site $(\mathrm{H}, \mathrm{M}$, or $\mathrm{L})$ using the GENMOD procedure of SAS. However, statistically significant differences were not found in the concentration of mycotoxins at different temperature sites. In addition to the temperature site effect, the effects of region and farm within region were included in the statistical model.

Considering these data, only descriptive statistics are presented; for each region, the incidence was calculated as the number of samples that tested positive in relation to the total number of samples. Means and standard deviations were calculated for the test-positive samples. As previously noted, aflatoxins $B_{2}, G_{1}$, and $G_{2}$ were not detected and were excluded from the statistical analysis.

\section{RESULTS AND DISCUSSION}

\section{Chemical Composition}

The mean chemical composition of the corn silage, the standard deviation, and the minimum and maximum values are reported in Table 1 . High variability was detected for the nutrient contents and other response variables, with a range of 48 to $988 \%$ between the minimum and maximum values. Despite the considerable information collected via the survey questionnaire, no significant correlations could be established to explain the variation in the response variables measured.

The DM content of the silage varied by $248 \%$, from extremely wet $(19.8 \% \mathrm{DM})$ to dry $(49.1 \% \mathrm{DM})$. Only $41.2 \%$ of the silage exhibited the recommended values, ranging from 30 to 35\% DM (Phipps et al., 2000). Wet silage (below $30 \%$ DM; $31.8 \%$ of the samples) can lead to effluent production and eventual clostridial growth due to major water activity and organic acid dilution. In contrast, dry silage (above $35 \%$ DM; $27 \%$ of the samples) is predisposed to heating and mold growth (Boudra and Morgavi, 2008). The samples that showed the greatest concentrations for ZEA, DON, $\mathrm{FB}_{1}$, and $\mathrm{FB}_{2}$ were $42.1,36.3,40.6$, and $37.1 \%$ of $\mathrm{DM}$, respectively; however, the lowest values were found at 33.1, $32.7,29.0$, and $33.7 \%$ of DM. Despite the low correlation coefficient between DM and PMI $(r=0.24)$, harvesting of corn at an ideal DM most likely contributes to reduced concentration of mycotoxins, probably due to less time in the field compared with high-maturity plants harvested 2 wk later or more.

The mean values for $\mathrm{CP}, \mathrm{NDF}$, and $\mathrm{ADF}(7.1 \pm 1.1 \%$, $52.5 \pm 5.4 \%$, and $26.3 \pm 4.1 \%$ of DM, respectively) are consistent with those reported for corn silage in Brazil (CQBAL, 2014). Ash and lignin showed the greatest variation compared with the other response variables measured. Six samples had ash contents $>6 \%$ of DM, most likely due to soil contamination or excessive DM losses during fermentation. The mean expected value for this variable is approximately $4 \%$ (NRC, 2001). 

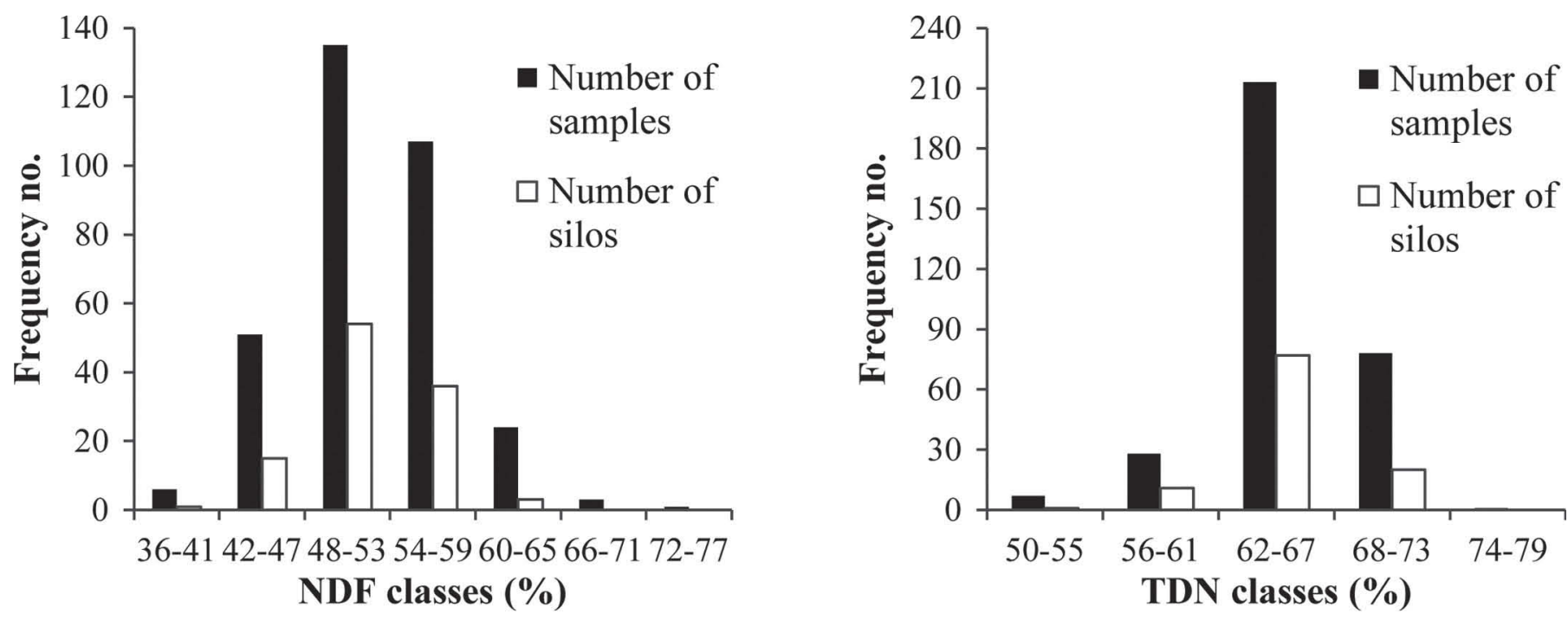

Figure 1. Number of samples $(\mathrm{n}=327)$ and silos $(\mathrm{n}=109)$ according to the NDF and TDN 5-unit classes.

Figure 1 shows the distribution of the samples and silos (mean of 3 samples from each silo) with respect to $\mathrm{NDF}$ and TDN classes. A concentration of NDF ranging from 48 to $53 \%$ was the most prevalent class; this range was present in $41.2 \%$ of the samples and $49.5 \%$ of the silos.

A low content of NDF, ranging from 36 to $41 \%$, was found in 6 samples, 2 of which were from the same silo. In 24 samples, NDF ranged from 60 to $65 \%$, but only 3 silos exhibited mean values in this class. Only 4 samples exhibited content of NDF $>66 \%$; each sample was from a different silo. These findings demonstrate the importance of adequate sample collection from silos when analyzing the chemical composition of silage. The typical practice in many farms is to sample a single spot that is considered to represent the entire silo, which can lead to errors in diet formulation.

The mean TDN $(65.2 \pm 3.6 \%)$ was lower than that reported by Tine et al. $(2001 ; 69.5 \%)$ and Skonieski et al. $(2014 ; 68.3 \%)$, most likely due to the lower lignin content reported by those authors for corn silage (1.5 and $2.9 \%$ of the DM, respectively). Lignin has a negative effect on calculated TDN values (Weiss et al., 1992) when ADL is used to calculate truly digestible fiber.

Concentrations of TDN ranging from 62 to $67 \%$ were observed in 213 of the 327 samples and on 77 of the 109 farms visited. Seven samples had TDN values $<55 \%$, and only 1 sample exhibited a value $>74 \%$ TDN. LowTDN silage negatively affects milk production because of a low supply of energy per NDF unit (Oba and Allen, 1999).

Ether extract content varied from 0.83 to $4.88 \%$ of the DM; these values are consistent with reports for corn silage in Brazil (CQBAL, 2014; Skonieski et al.,
2014). The high variability can be explained by the different commercial hybrids used in different farms, the harvesting time, and potential microbial degradation in air-exposed silage. Boyacioglu and Hettiarachchy (1995) observed a $43 \%$ reduction in the lipid content in wheat samples that grew Fusarium. However, Ono et al. (2006) found no correlation between the fumonisin concentration and protein or lipid fractions in corn kernels; the same trend is reported herein.

The mean lignin content $(4.0 \pm 1.3 \%)$ was similar to the $4.3 \%$ reported by Vilela et al. (2008) for corn silage in Brazil; however, it was greater than that described in NRC (2001) studies, which reported $3.1 \%$ lignin in 32 to $38 \%$ DM corn silage. Furthermore, high values (greater than $9 \% \mathrm{DM}$ ) were found in our study. Although some of this variation can be explained by the genetic profiles of the hybrids, fermentation loss during ensiling can contribute markedly to increased silage fiber content due to the loss of soluble compounds (McDonald et al., 1991).

The analyses in Tables 1 and 2 suggest that corn silage in Brazil is a highly variable feed; this variation can substantially affect animal performance depending on the chemical composition of the silage (Phipps et al., 2000). Thus, adopting tabulated values for diet formulations can lead to prediction errors in animal intake and performance. Unfortunately, this use of tabulated values remains a common practice on dairy farms in Brazil.

\section{Temperature}

The mean ambient temperature was $20.9 \pm 6.7^{\circ} \mathrm{C}$, ranging from $7.0^{\circ} \mathrm{C}$ to $36.0^{\circ} \mathrm{C}$ during the winter and 
Table 2. Descriptive statistics of the concentration of mycotoxins in corn silage in a farm survey $(\mathrm{n}=327)$

\begin{tabular}{|c|c|c|c|c|c|c|c|}
\hline Mycotoxin & $\begin{array}{l}\text { Incidence } \\
(\%)\end{array}$ & $\begin{array}{c}\text { Mean }^{1} \\
(\mu \mathrm{g} / \mathrm{kg} \text { of } \mathrm{DM})\end{array}$ & $\mathrm{SD}$ & Minimum & Maximum & $\mathrm{MAV}^{2}$ & $\begin{array}{l}\%> \\
\text { MAV }^{3}\end{array}$ \\
\hline Aflatoxin $\mathrm{B}_{1}$ & 0.9 & 3 & 3 & 1 & 6 & 19 & 0 \\
\hline Zearalenone & 72.8 & 181 & 278 & 10 & 1,830 & 285 & 10.1 \\
\hline Deoxynivalenol & 33.6 & 259 & 124 & 140 & 648 & 930 & 0 \\
\hline Fumonisin $B_{1}$ & 48.6 & 369 & 401 & 124 & 2,310 & 1,000 & 4.6 \\
\hline Fumonisin $\mathrm{B}_{2}$ & 25.1 & 261 & 215 & 113 & 1,380 & & \\
\hline
\end{tabular}

${ }^{1}$ Means calculated from samples with detectable values.

${ }^{2}$ Maximum acceptable value for corn silage, estimated according to the limits for daily intake of mycotoxins available from published data and international regulations; these values consider a standard high-producing cow that could consume up to $14 \mathrm{~kg}$ (DM) of corn silage per day.

${ }^{3}$ Percentage of samples with concentration values above MAV.

spring seasons in the subtropical and tropical regions of Brazil. The mean internal temperature $\left(28.8 \pm 7.7^{\circ} \mathrm{C}\right)$ was greater than the mean external temperature $(23.7$ $\left.\pm 6.6^{\circ} \mathrm{C}\right)$.

A temperature increase in silage is a consequence of microbial metabolism of substrates such as soluble carbohydrates and lactic acid (Kung et al., 2000). Therefore, a moderate and significant correlation was observed between the internal temperature and $\mathrm{pH}$. As expected, the effect of ambient temperature on infrared thermal measurements of a silo face was strong, as evidenced by the correlation $(\mathrm{r}=0.54 ; P<0.01)$ between AT and ET. Bowers et al. (2009) reported a strong correlation $(\mathrm{r}=0.92)$ between ambient temperature and the temperature of object surfaces measured using IRT. At a controlled room temperature $\left(25 \pm 1^{\circ} \mathrm{C}\right)$, the air-exposed silage temperatures measured by IRT were weakly correlated $(\mathrm{r}=0.04)$ with room temperature (Junges, 2010). Thus, IRT is useful for identifying heat spots on silo faces, but the temperatures must be carefully interpreted.

\section{Mycotoxins}

The incidence of each mycotoxin and the mean, minimum, and maximum concentrations of these mycotoxins are presented in Table 2 . The high variability in the concentration of mycotoxins is demonstrated by the high standard deviations and the large differences between the minimum and maximum concentrations for all mycotoxins. This result has also been reported in other surveys on the occurrence of mycotoxins in feedstuffs (Driehuis et al., 2008a; Cheli et al., 2013).

Aflatoxins $B_{2}, G_{1}$, and $G_{2}$ were not detected in any sample. The incidence of $\mathrm{AFB}_{1}$ was the lowest, with only 3 samples testing positive among the 327 samples, as previously reported by Acosta Aragón and Rodrigues (2009). Aflatoxins were not detected in a field survey performed in Holland by Driehuis et al. (2008b). These results support the notion that corn silage is not a relevant aflatoxin source in dairy cattle feed, most likely because of the poor tolerance of Aspergillus fungi to anaerobic and acid environments (Scudamore and Livesey, 1998). However, in poorly managed silage, the concentration of $\mathrm{AFB}_{1}$ can exceed $80 \mu \mathrm{g} / \mathrm{kg}$ (Borreani and Tabacco, 2010). At a high ambient temperature $\left(26-35^{\circ} \mathrm{C}\right)$ and humidity, the $\mathrm{AFB}_{1}$ concentration could increase (Cheli et al., 2013), which increases the risk of contamination at low latitudes (Klich, 2002).

Although OTA was found in 20 samples, 14 of these samples had concentrations above the suggested MAV. The low incidence of OTA $(6.1 \%)$ in this survey was consistent with published data (Garon et al., 2006; Boudra et al., 2007; Driehuis et al., 2008a), but the greatest concentration found $(62 \mu \mathrm{g} / \mathrm{kg})$ was extremely high, which indicates that under specific conditions, this mycotoxin may represent a high risk to corn silage. However, this mycotoxin is considered much less toxic for ruminants than for nonruminants because of the detoxification that occurs in the rumen (Mobashar et al., 2010). The OTA-producing fungus Aspergillus ochraceus does not grow at $8^{\circ} \mathrm{C}$ but develops rapidly at $25^{\circ} \mathrm{C}$ to $30^{\circ} \mathrm{C}$ (Palacios-Cabrera et al., 2005).

Zearalenone was the most prevalent mycotoxin and was found in 238 samples $(72.8 \%)$ at concentrations ranging from 10 to $1,830 \mu \mathrm{g} / \mathrm{kg}$. A total of 33 samples showed values above $285 \mu \mathrm{g} / \mathrm{kg}$, which is considered the critical value for corn silage. The ZEA concentration varied according to region, climate, and planting season, among other factors. There was a 100\% incidence in samples from the Castro region, and a high mean value $(334 \pm 374 \mu \mathrm{g} / \mathrm{kg})$ was detected. Coincidently, the Castro region has the most intensive dairy production in Brazil (Bernardes and do Rêgo, 2014); 29 of 32 farmers used self-propelled harvesters, and adequate to good bulk densities were observed in all silos. Samples from SC also showed a high incidence $(81.6 \%)$ of ZEA. These high incidences are most likely due to the wide variation between the day and night temperatures during crop growth in the summer in these regions. The 
correlation between IT and ZEA was low $(r=0.03)$, which indicates that aerobic degradation of silages is likely not an important cause of mycotoxin infection.

Acosta Aragón and Rodrigues (2009) analyzed 538 corn silage samples and found ZEA incidences of 23 and $48 \%$ in European and Asiatic countries, respectively, with mean values of 129 and $1,058 \mu \mathrm{g} / \mathrm{kg}$. The average concentration in this survey $(181 \pm 278 \mu \mathrm{g} /$ $\mathrm{kg}$ ) was similar to the value reported by Driehuis et al. (2008a; $146 \mu \mathrm{g} / \mathrm{kg})$.

Zearalenone is a metabolite produced by Fusarium species, mainly Fusarium graminearum, and it is often found in corn, wheat, barley, rice, sorghum, and silage (Jouany and Diaz, 2005). Under climate stress (drought or low temperatures), insect damage, or disease, crops become more vulnerable to Fusarium (Leslie et al., 1990; Teller et al., 2012). The growth of this fungus depends on temperature $\left(10^{\circ} \mathrm{C}\right.$ to $\left.40^{\circ} \mathrm{C}\right), \mathrm{pH}$ (4 to 8 ), and water activity $(>0.7)$. However, the ideal environment for fungal growth does not result in mycotoxin synthesis. At $25^{\circ} \mathrm{C}$, Fusarium species exhibit a normal growth rate without significant toxin production; however, at low temperature $\left(0^{\circ} \mathrm{C}\right)$, a strong increase in the ZEA concentration has been observed (Joffe, 1986). This observation is consistent with the findings herein.

Zearalenone and its metabolites bind to estrogen receptors (Diekman and Green, 1992) and cause reproductive disorders in mammals (Coulombe, 1993). The safe upper limit of ZEA intake by ruminants is unknown; typical diets contain different feed components, which can vary widely with respect to their mycotoxin profiles and concentrations. Therefore, the toxicity risks of balanced diets can be variable. The maximum acceptable value proposed for corn silage is $285 \mu \mathrm{g} / \mathrm{kg}$, which was determined by considering the data available from the literature (Table 2).

Brouk et al. (2011) found similar concentrations of ZEA in transgenic and conventional corn silages (632 and $648 \mu \mathrm{g} / \mathrm{kg}$, respectively). They verified that those silages do not affect dairy cow performance. Those values are greater than the mean value found in the current survey $(181 \pm 278 \mu \mathrm{g} / \mathrm{kg})$. The relationships between mycotoxins and silage production and between mycotoxins and management are not easy to understand. No correlation between ZEA and variables of feed-out management were detected in the current study. This finding demonstrates the strong influence of weather conditions on the content of this mycotoxin. Garon et al. (2006) observed minor variations (from 23 to $41 \mu \mathrm{g} / \mathrm{kg}$ ) in ZEA in corn silage during feedout from September to May in France. Eppley et al. (1974) found ZEA concentrations ranging from 400 to $5,000 \mu \mathrm{g} / \mathrm{kg}$ in corn kernels from Fusarium-damaged plants. Thus, good agronomic practices such as pest and disease control are likely the only opportunity to minimize environmental stress and decrease the risks of ZEA contamination of corn silage.

Fumonisins and DON were found in fewer than half of the samples evaluated, and the average values were below the MAV. Fumonisin $\mathrm{B}_{1}$ was found in 159 samples, and $\mathrm{FB}_{2}$ was present in 82 samples. Only 15 of the 327 samples had $\mathrm{FB}_{1}+\mathrm{FB}_{2}$ concentrations above the established limit $(1,000 \mu \mathrm{g} / \mathrm{kg})$; these mycotoxins are produced by Fusarium moniliforme and F. proliferatum strains under field stress. However, fumonisin contamination can arise in the postharvest stage from inefficient sealing (Fink-Gremmels, 2005; González-Pereyra et al., 2008). The extensive data collected in this survey (45 variables) did not explain the incidence or concentrations of these mycotoxins. Some trials suggest that ruminants are tolerant of high fumonisin concentrations (>5,000 $\mu \mathrm{g} / \mathrm{kg}$; Maragos and Richard, 1994; Prelusky et al., 1995), and concentrations of this mycotoxin warranting concern were not observed in this survey.

The average concentration of mycotoxins and incidence in the sampling classes according to the temperature of the silo face are presented in Figure 2. No pattern of distribution was observed, which was the hypothesis for establishing correlations among the temperature variables and PMI. Significant differences among the temperature sites were not detected for any mycotoxin.

A total of 21 variables were evaluated for each sample. The variables with significant correlations are presented in Table 3. Moderate to strong correlations were not detected for any variable except ET, which was measured using the infrared thermometer and was positively correlated $(\mathrm{r}=0.54)$ with AT. Chemical composition was not correlated with the temperature variables. A moderate correlation was detected between IT and $\mathrm{pH}(\mathrm{r}=0.38)$ as well as between the TDN and DM content $(\mathrm{r}=0.37)$. The PMI was significantly correlated with ET, AT, DM, and TDN, but the correlation coefficients were low.

Fungi do not grow during the anaerobic phase of silage because of their low tolerance to acidic environments without oxygen (McDonald et al., 1991). Thus, mycotoxin production during the fermentation process could be considered negligible if correct management practices such as adequate compression and sealing are applied. However, the low $\mathrm{pH}$ of the substrate and the presence of amines can stimulate DON production by Fusarium graminearum (Gardiner et al., 2009). Teller et al. (2012) reported an increase in Fusarium toxin after ensilage; its effect is stronger at sites undergoing aerobic deterioration (Borreani and Tabacco, 2010). However, the preharvest phase appears to be the most important phase for Fusarium toxin contamination of 
Table 3. Correlation coefficients ${ }^{1}$ (above the diagonal) and $P$-values (below the diagonal) between the internal (IT) or external (ET) temperature of a silo face, ambient temperature (AT), DM content, pH, TDN, and ponderal mycotoxin index (PMI) for corn silage in a farm survey

\begin{tabular}{lrrrrrrr}
\hline & ET & \multicolumn{1}{c}{ IT } & AT & DM & pH & TDN & PMI \\
\hline ET & & 0.36 & 0.54 & 0.08 & 0.08 & 0.01 & -0.19 \\
IT & $<0.01$ & & 0.11 & 0.12 & 0.38 & -0.05 & -0.10 \\
AT & $<0.01$ & 0.06 & & 0.08 & -0.00 & 0.05 & -0.20 \\
DM & 0.13 & 0.04 & 0.23 & & 0.24 & 0.37 & 0.24 \\
pH & 0.16 & $<0.01$ & 0.68 & $<0.01$ & & 0.01 & 0.06 \\
TDN & 0.97 & 0.35 & 0.39 & $<0.01$ & 0.96 & & 0.17 \\
PMI & $<0.01$ & 0.07 & $<0.01$ & $<0.01$ & 0.33 & $<0.01$ & \\
\hline
\end{tabular}

${ }^{1}$ The mean values are listed in Table 1.
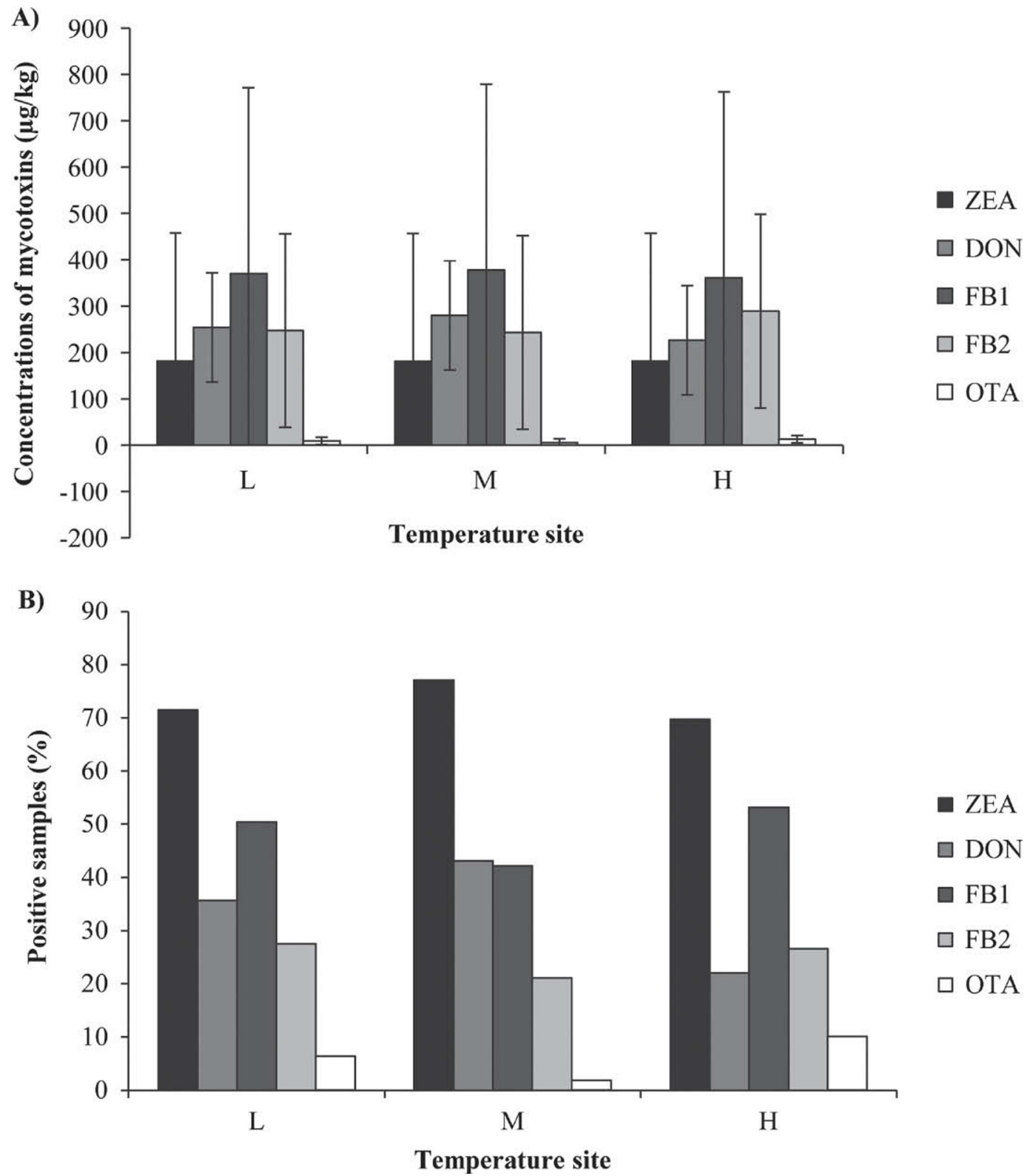

Figure 2. The average concentration $( \pm \mathrm{SD})$ of mycotoxins $(\mathrm{A} ; \mu \mathrm{g} / \mathrm{kg}$ of $\mathrm{DM})$ and incidence (B; \% of positive test results) according to the following sampling sites on a silo face: the lowest temperature $\left(\mathrm{L}, 20.8 \pm 5.5^{\circ} \mathrm{C}\right)$, a medium temperature $\left(\mathrm{M}, 23.9 \pm 5.9^{\circ} \mathrm{C}\right)$, and the highest temperature $\left(\mathrm{H}, 26.5 \pm 7.1^{\circ} \mathrm{C}\right) . \mathrm{ZEA}=$ zearalenone; $\mathrm{DON}=$ deoxynivalenol; $\mathrm{FB}_{1}=$ fumonisin $\mathrm{B}_{1} ; \mathrm{FB}_{2}=$ fumonisin $\mathrm{B}_{2}$; and $\mathrm{OTA}=$ ochratoxin $\mathrm{A}$. 
Table 4. Mean values $( \pm \mathrm{SD})$ of test-positive samples $(\mu \mathrm{g} / \mathrm{kg}$ of $\mathrm{DM})$ and mycotoxin incidence (number of positive samples/total) in each of the regions surveyed

\begin{tabular}{lcccccc}
\hline & \multicolumn{7}{c}{ Mycotoxin $^{2}$} \\
\cline { 2 - 6 } Region $^{1}$ & AFB $_{1}$ & ZEA & OTA & DON & FB $_{1}$ & FB $_{2}$ \\
\hline CA & $4 \pm 3$ & $334 \pm 374$ & $4 \pm 1$ & $208 \pm 92$ & $316 \pm 258$ & $199 \pm 91$ \\
& $(2 / 96)$ & $(96 / 96)$ & $(5 / 96)$ & $(7 / 96)$ & $(42 / 96)$ & $(15 / 96)$ \\
TL & - & $75 \pm 85$ & 5 & $276 \pm 131$ & $273 \pm 148$ & $209 \pm 79$ \\
& & $(34 / 60)$ & $(1 / 60)$ & $(30 / 60)$ & $(31 / 60)$ & $(19 / 60)$ \\
GO & - & $48 \pm 44$ & 11 & $221 \pm 71$ & $201 \pm 80$ & $143 \pm 13$ \\
& & $(14 / 42)$ & $(1 / 42)$ & $(12 / 42)$ & $(11 / 42)$ & $(5 / 42)$ \\
MG & - & $(4 \pm 69$ & $15 \pm 23$ & $264 \pm 107$ & $567 \pm 619$ & $352 \pm 305$ \\
& & $(44 / 69)$ & $(6 / 69)$ & $(36 / 69)$ & $(48 / 69)$ & $(32 / 69)$ \\
SC & 1 & $92 \pm 127$ & $12 \pm 8$ & $264 \pm 161$ & $277 \pm 203$ & $226 \pm 122$ \\
& $(1 / 60)$ & $(49 / 60)$ & $(7 / 60)$ & $(25 / 60)$ & $(27 / 60)$ & $(11 / 60)$ \\
\hline
\end{tabular}

${ }^{1} \mathrm{CA}=$ Castro, Paraná State; TL = Toledo, Paraná State; GO = Goiás State; MG = Minas Gerais State; and $\mathrm{SC}=$ Santa Catarina State.

${ }^{2} \mathrm{AFB} 1=$ aflatoxin $\mathrm{B}_{1} ; \mathrm{ZEA}=$ zearalenone; $\mathrm{OTA}=$ ochratoxin $\mathrm{A} ; \mathrm{DON}=$ deoxynivalenol; $\mathrm{FB}_{1}=$ fumonisin $\mathrm{B}_{1}$; and $\mathrm{FB}_{2}=$ fumonisin $\mathrm{B}_{2}$.

leaves, stems, cobs, and corn kernels. Damaged corn plants yielded a high DON concentration in silage $(920$ $\mu \mathrm{g} / \mathrm{kg})$ compared with healthy plants $(3.1 \mu \mathrm{g} / \mathrm{kg}$; Teller et al., 2012).

In this survey, DON was detected in 110 out of 327 samples, averaging $259 \pm 124 \mu \mathrm{g} / \mathrm{kg}$. None of the samples showed DON concentrations greater than the MAV $(930 \mu \mathrm{g} / \mathrm{kg})$. An incidence of $53 \%$ and a mean value of $550 \mu \mathrm{g} / \mathrm{kg}$ were observed in 47 samples from Holland (Driehuis et al., 2008a). Research data from Europe and the United States from 1989 to 2007 indicated an incidence of DON ranging from 72 to $100 \%$ and mean values ranging from 600 to $1,850 \mu \mathrm{g} / \mathrm{kg}$ (Driehuis, 2011). These observations illustrate the difficulty of comparing different databases to establish reference values for corn silage because DON incidence and concentration are dependent on local variables such as climate, corn hybrid, and crop management. This difficulty is also obvious when mycotoxin incidences in different regions of Brazil are compared.

The average concentration of mycotoxins and their incidence in each region are presented in Table 4. Aflatoxin $\mathrm{B}_{1}$ was only detected at low concentrations in 2 regions, whereas ZEA was found in all samples collected in Castro at a high average concentration. In $\mathrm{SC}$, the mean value and incidence of ZEA were also high. The mean values of OTA in GO, MG, and SC were above the MAV; however, the incidence was low. On average, DON was not a concern in corn silage in any of the regions surveyed; generally, it was found in fewer than half of the samples at mean values below the MAV. A similar result was observed for fumonisin concentrations in corn silage.

Despite the experimental protocol and considerable number of variables investigated, the relationship between feed-out management and mycotoxin incidence remains unclear. In the present study, we found that silage temperature is not a good predictor of the presence of mycotoxins that have been analyzed, and the preharvest phase can strongly affect the concentration of mycotoxins, even in well-managed silage without heat sites.

\section{CONCLUSIONS}

Infrared thermography is a useful tool for identifying heat sites on a silo face; however, the temperature values do not represent the internal temperature of the silage because ambient variables interfere with this measurement. Temperature is not an appropriate indicator of mycotoxin incidence or concentration. The mycotoxin profile of corn silage and its chemical composition are highly variable and do not directly correlate with silage temperature. The analyzed mycotoxins, and especially aflatoxins, in Brazilian corn silages do not appear to be a concern. However, the climate of certain regions can predispose silages to mycotoxin incidence, and this incidence must be monitored.

\section{ACKNOWLEDGMENTS}

The authors thank the National Council of Technological and Scientific Development (CNPq; Brasília, Distrito Federal, Brazil) for supporting this trial.

\section{REFERENCES}

Acosta Aragón, Y., and I. Rodrigues. 2009. The occurrence of mycotoxins in silages. Pages 201-202 in Proc. Int. Silage Conf. Univ. Wisconsin, Madison.

AOAC International. 1998. Official Methods of Analysis. 16th ed. AOAC International, Gaithersburg, MD. 
AOCS (American Oil Chemists' Society). 2008. Official Methods and Recommended Practices of the American Oil Chemists' Society. 5th ed. AOCS, Urbana, IL.

Bernardes, T. F., and A. C. do Rêgo. 2014. Study on the practices of silage production and utilization on Brazilian dairy farms. J. Dairy Sci. 97:1852-1861.

Borreani, G., and E. Tabacco. 2010. The relationship of silage temperature with the microbiological status of the face of corn silage bunkers. J. Dairy Sci. 93:2620-2629.

Boudra, H., J. Barnouin, S. Dragacci, and D. P. Morgavi. 2007. Aflatoxin $\mathrm{M}_{1}$ and ochratoxin $\mathrm{A}$ in raw bulk milk from French dairy herds. J. Dairy Sci. 90:3197-3201.

Boudra, H., and D. Morgavi. 2008. Reduction in Fusarium toxin levels in corn silage with low dry matter and storage time. J. Agric. Food Chem. 56:4523-4528.

Bowers, S., S. Gandy, B. Anderson, P. Ryan, and S. Willard. 2009 Assessment of pregnancy in the late-gestation mare using digital infrared thermography. Theriogenology 72:372-377.

Boyacioglu, D., and N. S. Hettiarachchy. 1995. Changes in some biochemical components of wheat grain that was infected with $F u$ sarium graminearum. J. Cereal Sci. 21:57-62.

Brouk, M. J., B. Cvetkovic, D. W. Rice, B. L. Smith, M. A. Hinds, F. N. Owens, C. Lians, and T. E. Sauber. 2011. Performance of lactating dairy cows fed corn as whole plant silage and grain produced from genetically modified corn containing event DAS-591227 compared to a nontransgenic, near-isogenic control. J. Dairy Sci. 94:1961-1966.

Cheli, F., A. C. Ampagnoli, and V. Dell'Orto. 2013. Fungal populations and mycotoxins in silages: From occurrence to analysis. Anim. Feed Sci. Technol. 183:1-16.

Coppock, R. W., M. S. Mostrom, C. G. Sparling, B. Jacobsen, and S. C. Ross. 1990. Apparent zearalenone intoxication in a dairy herd from feeding spoiled acid-treated corn. Vet. Hum. Toxicol. $32: 246-248$.

Coulombe, R. A. Jr. 1993. Biological action of mycotoxins. J. Dairy Sci. 76:880-891.

CQBAL. 2014. Tabelas Brasileiras de Composição de Alimentos para Bovinos. Accessed May 20, 2014. http://cqbal.agropecuaria.ws/ webcqbal.

Diekman, M. A., and M. L. Green. 1992. Mycotoxins and reproduction in domestic livestock. J. Anim. Sci. 70:1615-1627.

Driehuis, F. 2011. Occurrence of mycotoxins in silage. Pages 85-103 in Proc. Int. Symp. Forage Quality and Conservation, São Pedro, SP, Brazil. FEALQ, Piracicaba, Brazil.

Driehuis, F., M. C. Spanjer, J. M. Scholten, and M. C. te Giffel. 2008a. Occurrence of mycotoxins in feedstuffs of dairy cows and estimation of total dietary intakes. J. Dairy Sci. 91:4261-4271.

Driehuis, F., M. C. Spanjer, J. M. Scholten, and M. C. Te Giffel 2008b. Occurrence of mycotoxins in maize, grass and wheat silage for dairy cattle in the Netherlands. Food Addit. Contam. B Surveill. 1:41-50

Eppley, R. M., L. Atoloff, M. W. Trucksess, and C. W. Chung. 1974 Survey of corn for Fusarium toxins. J. Assoc. Off. Anal. Chem. $57: 632-635$.

Fink-Gremmels, J. 2005. Mycotoxins in forages. Pages 249-268 in The Mycotoxins Blue Book. D. E. Diaz, ed. Nottingham University Press, Nottingham, UK

FAO (Food and Agriculture Organization). 2003. Mycotoxin regulations in 2003 and current developments. Accessed Mar. 24, 2011. http://www.fao.org/3/a-y5499e.pdf.

FDA (Food and Drug Administration). 2001. Guidance for industry: Fumonisin levels in human foods and animal feeds. Fed. Regist. $66: 56688-56689$.

Gardiner, D. M., S. Osborne, K. Kazan, and J. M. Manners. 2009 Low $\mathrm{pH}$ regulates the production of deoxynivalenol by Fusarium graminearum. Microbiology 155:3149-3156.

Garon, D., E. Richard, L. Sage, V. Bouchart, D. Pottier, and P. Lebailly. 2006. Mycoflora and multimycotoxin detection in corn silage experimental study. J. Agric. Food Chem. 54:3479-3484.
Goering, H. K., and P. J. Van Soest. 1970. Forage Fiber Analyses (Apparatus, Reagents, Procedures, and Some Applications). Agric. Handbook No. 379. ARS-USDA, Washington, DC.

González-Pereyra, M. L., V. A. Alonso, R. Sager, M. B. Morlaco, C E. Magnoli, A. L. Astoreca, C. A. da Rosa, S. M. Chiacchiera, A. M. Dalcero, and L. R. Cavaglieri. 2008. Fungi and select mycotoxins from pre- and postfermented corn silage. J. Appl. Microbiol. 104:1034-1041.

Helferich, W. G., W. N. Garrett, D. P. H. Hsieh, and R. L. Baldwin. 1986. Feedlot performance and tissue residues of cattle consuming diets containing aflatoxins. J. Anim. Sci. 62:691-696.

Ingalls, J. R. 1996. Influence of deoxynivalenol on feed consumption by dairy cows. Anim. Feed Sci. Technol. 60:297-300.

Joffe, A. Z. 1986. Fusarium Species: Their Biology and Toxicology. John Wiley and Sons, New York, NY.

Jouany, J. P., and D. E. Diaz. 2005. Effects of mycotoxins in ruminants. Pages 295-320 in The Mycotoxins Blue Book. D. E. Diaz, ed. Nottingham University Press, Nottingham, UK.

Junges, D. 2010. Aditivo microbiano na silagem de milho em diferentes tempos de armazenamento e avaliação da estabilidade aeróbia por termografia em infravermelho. MS Thesis. Univ. Fed. do Paraná, Curitiba, Brazil.

Klich, M. A. 2002. Biogeography of Aspergillus species in soil and litter. Mycologia 94:21-27.

Kung, L. Jr., D. B. Grieve, J. W. Thomas, and J. T. Huber. 1984 Added ammonia or microbial inoculate for fermentation and nitrogenous compounds of alfalfa ensiled at various percents of dry matter. J. Dairy Sci. 67:299-306.

Kung, L. Jr., J. R. Robinson, N. K. Ranjit, J. H. Chen, C. M. Golt, and J. D. Pesek. 2000. Microbial populations, fermentation end-products, and aerobic stability of corn silage treated with ammonia or a propionic acid-based preservative. J. Dairy Sci. 83:1479-1486.

Leslie, J. F., C. A. S. Pearson, P. E. Nelson, and T. A. Toussoun. 1990. Fusarium spp. from corn, sorghum, and soybean fields in the central and eastern United States. Phytopathology 80:343-350.

Maragos, C. M., and J. L. Richard. 1994. Quantitation and stability of fumonisins B1 e B2 in milk. J. AOAC Int. 77:1162-1167.

McDonald, P., A. R. Henderson, and S. J. E. Heron. 1991. The Biochemistry of Silage. 2nd ed. Chalcombe Publications, Lincoln, UK.

Mobashar, M., J. Hummel, R. Blank, and K. H. Südekum. 2010. Ochratoxin $\mathrm{A}$ in ruminants - $\mathrm{A}$ review on its degradation by gut microbes and effects on animals. Toxins (Basel) 2:809-839.

NRC. 2001. Nutrients Requirements of Dairy Cattle. 7th rev. ed. Natl. Acad. Press, Washington, DC.

Oba, M. and M. S. Allen. 1999. Evaluation of the importance of the digestibility of neutral detergent fiber from forage: Effects on dry matter intake and milk yield of dairy cows. J. Dairy Sci. 82:589-596

Ono, E. Y. S., L. Biazon, M. Silva, E. Vizoni, Y. Sugiura, Y. Ueno, and E. Hirooka. 2006. Fumonisins in corn: Correlation with Fusarium sp. count, damaged kernels, protein and lipid content. Braz. Arch. Biol. Technol. 49:63-71.

Palacios-Cabrera, H., M. H. Taniwaki, J. M. Hashimoto, and H. C. Menezez. 2005. Growth of Aspergillus ochraceus, A. carbonarius and $A$. niger on culture media as different water activities and temperatures. Braz. J. Microbiol. 36:24-28.

Phipps, R. H., J. D. Sutton, D. E. Beever, and A. K. Jones. 2000. The effect of crop maturity on the nutritional value of maize silage for lactating dairy cows: 3 . Food intake and milk production. J. Anim. Sci. 71:401-409.

Prelusky, D. B., M. E. Savard, and H. L. Trenholm. 1995. Pilot study on the plasma pharmacokinetics of fumonisin B1 in cows following a single dose by oral gavage or intravenous administration. Nat. Toxins 3:389-394.

Richard, J. L., G. Meerdink, C. M. Maragos, M. Tumbleson, G. Bordson, L. G. Rice, and P. F. Ross.1996. Absence of detectable fumonisins in the milk of cows fed Fusarium proliferatum (Matsushima) Nirenberg culture material. Mycopathologia 133:123-126. 
Scudamore, K. A., and C. T. Livesey. 1998. Occurrence and significance of mycotoxins in forage crops and silage: A review. J. Sci. Food Agric. 77:1-17.

Skonieski, F. R., J. L. Nörnberg, J. D. Kessler, D. B. David, E. B. Azevedo, G. Brüning, and C. M. M. Pimentel. 2014. Corn plant arrangement and its effect on silage quality. Rev. Bras. Zootec. 43:114-119.

Sniffen, C. J., J. D. O'Connor, P. J. Van Soest, D. G. Fox, and J. B. Russell. 1992. A net carbohydrate and protein system for evaluating cattle diets: II. Carbohydrate and protein availability. J. Anim. Sci. 70:3562-3577.

Teller, R. S., R. J. Schmidt, L. W. Whitlow, and L. Kung Jr.. 2012. Effect of physical damage to ears of corn before harvest and treatment with various additives on the concentration of mycotoxins, silage fermentation, and aerobic stability of corn silage. J. Dairy Sci. 95:1428-1436.

Tine, M. A., K. R. McLeod, R. A. Erdman, and R. L. Baldwin. 2001. Effects of brown midrib corn silage on the energy balance of dairy cattle. J. Dairy Sci. 84:885-895.

Van Soest, P. J., J. B. Robertson, and B. A. Lewis. 1991. Methods for dietary fiber, neutral detergent fiber, and non-starch polysaccharides in relation to animal nutrition. J. Dairy Sci. 74:3583-3597.
Varga, E., T. Glauner, R. Köppen, K. Mayer, M. Sulyok, R. Schuhmacher, R. Krska, and F. Berthiller. 2012. Stable isotope dilution assay for the accurate determination of mycotoxins in maize by UHPLC-MS/MS. Anal. Bioanal. Chem. 402:2675-2686.

Vilela, H. H., A. V. Rezende, P. F. Vieira, G. A. Andrade, A. R. Evangelista, and G. B. S. Almeida. 2008. Valor nutritivo de silagens de milho colhido em diversos estádios de maturação. Rev. Bras. Zootec. 37:1192-1199.

Weiss, W. P., H. R. Conrad, and N. R. Pierre. 1992. A theoreticallybased model for predicting total digestible nutrient values of forages and concentrates. Anim. Feed Sci. Technol. 39:95-110.

Wiles, P. G., I. K. Gray, and R. C. Kissling. 1998. Routine analysis of protein by Kjeldahl and Dumas methods: Review and interlaboratory study using dairy products. J. AOAC Int. 81:620-632.

Wood, G. E., and M. W. Trucksess. 1998. Regulatory control programs for mycotoxin-contaminated food. Pages 459-481 in Mycotoxins in Agriculture and Food Safety. K. K. Sinha and D. Bhatnagar, ed. Marcel Dekker, New York, NY. 